\title{
ESTIMATIONS OF THE DIFFERENCE OF TWO INTEGRAL MEANS VIA EULER-TYPE IDENTITIES
}

\author{
J. PEČARIĆ, I. PERIĆ AND A. VUKELIĆ
}

Abstract. Generalizations of estimations of difference of two integral means are given, by using Euler-type identities.

Mathematics subject classification (2000): 26D15, 26D20, 26 D99.

Key words and phrases: Ostrowski inequality, Bernoulli polynomials, bounded variation.

\section{REFERENCES}

[1] M. Abramowitz And I. A. Stegun (EDS), Handbook of mathematical functions with formulae, graphs and mathematical tables, National Bureau of Standards, Applied Math. Series 55, 4th printing, Washington 1965 .

[2] N. S. Barnett, P. Cerone, S. S. Dragomir And A. M. FinK, Comparing two integral means for absolutely continuous mappings whose derivatives are in $L_{\infty}[a, b]$ and applications, RGMIA Res. Rep. Coll., Vol. 3, No. 2, (2000).

[3] I. S. Berezin And N. P. Zhidkov, Computing methods, Vol. I. Pergamon Press, Oxford-LondonEdinburgh-New York-Paris-Frankfurt, 1965.

[4] P. CERone And S. S. Dragomir, Diferences between means with bounds from a Riemann-Stieltjes integral, RGMIA Res. Rep. Coll., Vol. 4, No. 2, (2001).

[5] P. CERONE AND S. S. Dragomir, On some inequalities arising Montogomery's identity, RGMIA Res. Rep. Coll., Vol. 3, No. 2, (2000).

[6] LJ. Dedić, M. MATIĆ AND J. PEČARIĆ, On generalization of Ostrowski inequality via some Euler-type identities, Math. Inequal. Appl., Vol. 3, No. 3, (2000), 337-353.

[7] LJ. DEDIĆ, M. MATIĆ, J. PEČARIĆ AND A. VuKELIĆ, On generalization of Ostrowski inequality via Euler harmonic identities, J. of Inequal. and Appl., 7(6) (2002), 787-805.

[8] S. S. DRAGOMIR AND S. WANG, A new inequality of Ostrowski's type in $L_{p}$ norm and applications to some special means and to some numerical quadrature rules, Indian Journal of Mathematics, 40 (3)(1998), 299-304.

[9] S. S. Dragomir, R. P. Agarwal AND N. S. BARnett, Inequalities for Beta and Gamma functions via some classical and new inequalities, Journal of Inequalities and Applications 5(2000), 103-165.

[10] A. M. FINK, Bounds of the deviation of a function from its avereges, Czechoslovak Math. J., 42(117) (1992), 289-310.

[11] V. I. KRYLOV, Approximate calculation of integrals, Macmillan, New York-London, 1962

[12] M. Matić And J. PeČARIć, Two-point Ostrowski inequality, Math. Inequal. Appl., Vol. 4, No. 2, (2001), $215-221$.

[13] A. OsTROWSKI, Über die Absolutabweichung einer differentiebaren Funktion von ihren Integralmittelwert, Comment. Math. Helv. 10 (1938), pp. 226-227. 